\title{
Double GPCR trouble
}

Glutamatergic and serotoninergic systems have been implicated in psychotic disorders. González-Maeso and colleagues, writing in Nature, show that 5-hydroxytryptamine (5-HT) $2 \mathrm{~A}$ receptors $\left(5-\mathrm{HT}_{2 \mathrm{~A}} \mathrm{R}\right)$ - through which many existing antipsychotic drugs act - and metabotropic type-2 glutamate receptors $\left(\mathrm{mGluR}_{2}\right)$ - which are potential new anti-psychotic targets - form complexes that might be involved in schizophrenia.

It has been suggested that many members of the G-protein-coupled receptor (GPCR) family can exist as oligomeric complexes. Two findings led the authors to posit that this could occur with 5- $\mathrm{HT}_{2 \mathrm{~A}} \mathrm{R}$ and $\mathrm{mGluR}_{2}$ : mRNA for the two receptors was colocalized in mouse neuronal cultures, and $\mathrm{mGluR}_{2}$ protein levels were decreased in

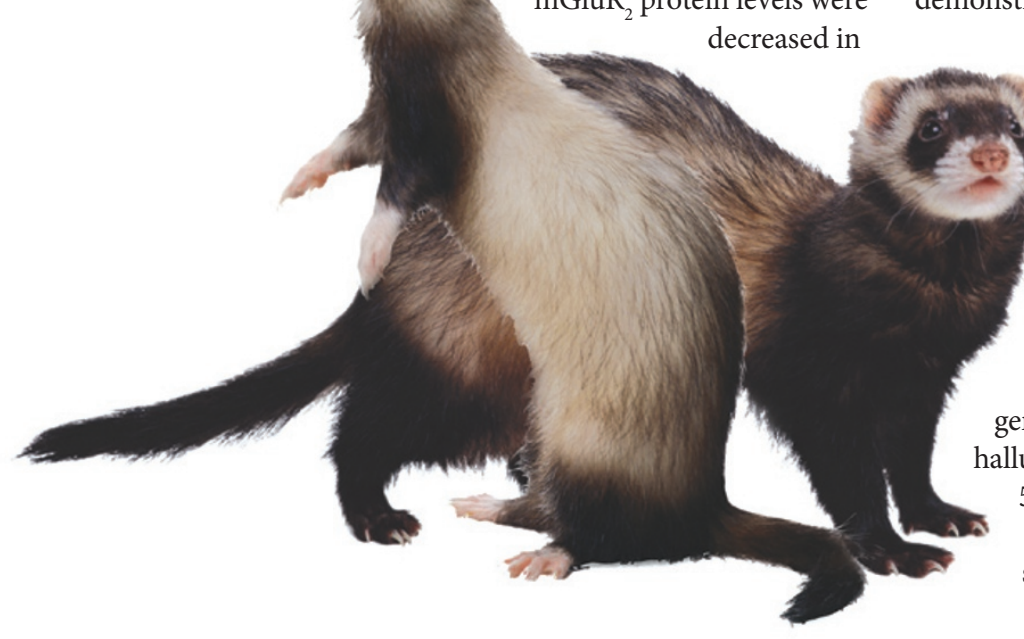

5- $\mathrm{HT}_{2 \mathrm{~A}} \mathrm{R}-\mathrm{knock}$ out mice. Evidence for the existence of $5-\mathrm{HT}_{2 \mathrm{~A}} \mathrm{R}-\mathrm{mGluR}_{2}$ complexes was obtained by co-immunoprecipitation and resonance-energy-transfer studies.

Competition-binding experiments, in which an $\mathrm{mGluR}_{2 / 3}$ agonist increased the affinity of three hallucinogenic $5-\mathrm{HT}_{2 \mathrm{~A}} \mathrm{R}$ agonists for the 5-HT-binding site, and in which a $5-\mathrm{HT}_{2 \mathrm{~A}} \mathrm{R}$ agonist decreased the affinity of the three mGluR $_{2 / 3}$ agonists for the glutamate-binding site, suggested that the $5-\mathrm{HT}_{2 \mathrm{~A}} \mathrm{R}-\mathrm{mGluR}_{2}$ complex might serve to integrate serotonin and glutamate signalling. Furthermore, by measuring the regulation of specific G-protein subunits, the receptor complex was shown to modulate G-protein coupling. Using molecular chimaeras of $\mathrm{mGluR}_{2}$ and mGluR $_{3}$ - the latter of which did not form complexes - the authors demonstrated that the segment of $\mathrm{mGluR}_{2}$ that contains transmembrane helices 4 and 5 was necessary and sufficient for the formation of a complex with $5-\mathrm{HT}_{2 \mathrm{~A}} \mathrm{R}$.

In the mouse cortex and in primary cortical cultures, the induction of early growth response gene 2 - a specific marker for hallucinogen signalling through 5- $\mathrm{HT}_{2 \mathrm{~A}} \mathrm{R}$ - was blocked by an $\mathrm{mGluR}_{2 / 3}$ agonist that also suppressed the induction of hallucinogen-specific head-twitch behaviour in vivo. This suggested that the $5-\mathrm{HT}_{2 \mathrm{~A}} \mathrm{R}-\mathrm{mGluR}_{2}$ complex might be important for hallucinogen signalling and behaviour.

As the neuropsychological effects of hallucinogenic drugs present commonalities with the psychosis of schizophrenia, the authors investigated whether the components of the $5-\mathrm{HT}_{2 \mathrm{~A}} \mathrm{R}-\mathrm{mGluR}_{2}$ signalling complex were altered in the cortex of subjects with schizophrenia. Drug-naïve schizophrenic subjects showed increased 5- $\mathrm{HT}_{2 \mathrm{~A}} \mathrm{R}$ levels and decreased $\mathrm{mGluR}_{2}$ levels. This, combined with the observation that activation of the $\mathrm{mGluR}_{2}$ component of the $5-\mathrm{HT}_{2 \mathrm{~A}} \mathrm{R}-\mathrm{mGluR}_{2}$ complex eliminates the hallucinogen-specific signalling, suggests that the increased $5-\mathrm{HT}_{2 \mathrm{~A}} \mathrm{R}$ and decreased $\mathrm{mGluR}_{2}$ found in the brain in schizophrenia might predispose to a hallucinogenic pattern of signalling.

Although further work is needed to investigate whether the $5-\mathrm{HT}_{2 \mathrm{~A}} \mathrm{R}-\mathrm{mGluR}_{2}$ complex could be targeted for the treatment of psychosis, this study provides evidence of a GPCR complex with functional relevance and therapeutic potential.

Charlotte Harrison

\section{ORIGINAL RESEARCH PAPER}

González-Maeso, J. et al. Identification of a serotonin/glutamate receptor complex implicated in psychosis. Nature 452, 93-97 (2008) 